\title{
Silent Bergman Full of Words
}

\author{
Andrea Hanáčková - Tomáš Bojda
}

\begin{abstract}
Ingmar Bergman, in addition to producing a large number of films, also worked for the theatre and in radio. All of his activities were intertwined and influenced one another. The paper outlines Bergman's traces in radio with an emphasis on Czech radio production. It reflects the biographic readings, monodrama, dialogic plays as well as more extensive plays which, thanks to their intimate setting, the intensity of relationships among characters and meaning, correspond to the character of Bergman's late work. Relying on the analyses by Jess Kalin and radio theoreticians Martin Shingler and Cindy Wieringa, the authors look into the imaginativeness of Bergman's plays with a particular focus on the dimensions of silence and words.
\end{abstract}

\section{Keywords}

Ingmar Bergman, film, radio play, Jesse Kalin, radio adaptation, silence, Czech radio, Josef Henke 
To my amazement, the hands of the clock had disappeared. The dial was blank, and below it someone had smashed both of the eyes so that they looked like watery, infected sores. Instinctively I pulled out my own watch to check the time, but I found that my old reliable gold timepiece had also lost its hands. I held it to my ear to find out if it was still ticking. Then I heard my heart beat. It was pounding very fast and irregularly. I was overwhelmed by an inexplicable feeling of frenzy.

(Ingmar Bergman: Wild Strawberries, BERGMAN 1960: 171)

We quote one of Bergman's most famous film scenes, Isak Borg's surrealist nightmare in silence. The quality of each shot that follows is amplified by the absence of any sound. Before the arrival of the horse-drawn carriage with the coffin, the confused Borg moves around in a strange town in an absolute timelessness and silence. The silent dream, however, functions as a trigger of words. The hero sets out on a journey, descends into his inner feelings, and re-evaluates his life and existence among people. The radio plays by Ingmar Bergman are similar in nature. The features of all his radio plays are: the evocation of a silent place, recollection, and characters entering reality in a somewhat slow and reluctant manner. Bergman appears to be an ideal author for the intimacy of the radio as a medium. Therefore, the following reflections will rely on the adaptation of Bergman's film scripts for the radio and several original radio plays. The paper mainly covers Czech radio in 1966, when Bergman was first broadcast (comparatively late compared with Western countries). He was reputed to be a complicated author of psychological films and, moreover, since The Silence (1963) critics in socialist Czechoslovakia had labelled him a scandalous author, a filmmaker offering daring erotic scenes and as such he was an unwelcome element.

While considering the specifics of Bergman's plays, we will work with the terminology of structuralist radio theory that mentions radio dimensions ${ }^{1}$ of silence and words. Regarding the method, of crucial importance for us is the concept of Martin Shingler and Cindy Wieringa who most intensely connect the dimension of silence with the dimension of the listener's imagination: 'Silence must be radio's most underestimated and least understood code. Seemingly not a code at all, silence can actually be one of the medium's most evocative.' (SHINGLER - WIERINGA 1998: 54). According to Shingler, moods, emotions, atmospheres and environments are the most frequently used ways in which silence can influence and amplify the listener's experience. The Czech theoretician of sound dramaturgy Ivo Bláha points out that silence is an 'irreplaceable means of expressing profound emotional strength' (BLÁHA 2004: 5). However, rather than with the position of silence in the work's structure, we are concerned with the presence of the 'inner silence', most often expressed by a monologue, the so-called 'inner voice' (CROOK 1999: 222) - the silence that enables one to come to themselves, to

1 Dimension is Tim Crook's term (CROOK 1999). Richard J. Hand and Mary Traynor refer to words, music, sound and silence as elements (HAND - TRAYNOR 2011). 
find certain words and with them describe one's position in the world. Such a description of silence is very close to other words, such as loneliness, anxiety, and threat. But, paradoxically, there is also a meaning of security, self-assurance, and calm. A similar duality of silence often reflects the frequent state of being in Bergman's characters. This is why one of our sources will be the poet and radio theoretician Seán Street who dedicated a chapter in his publication The Poetry of Radio. The Colour of Sound, having named it characteristically Silence: Fear and Possibility (STREET 2014).

We reflect the relationship between words and silence in the radio plays by Ingmar Bergman in the Czech language, taking into account some film titles. American film studies professor Jesse Kalin discloses Bergman's creative methods (KALIN 2003). He analyses Bergman's authorial impulses, concentrates on the existentialist principles of his films, and emphasises the moral aspects and ethical legacy of the director's work. In our paper, we proceed in a similar manner. At the same time, we examine what impact the actors' performance has on creating tension between: words and silence; excitation and calm; and life and death. The paper describes the Czech production of the Swedish author's work on radio and discovers how differently the directors interpreted his early and later works.

\section{Radio Director Bergman and Wood Painting}

Silence is a doorway to memory, expectation, anticipation, fear. (STREET 2014: 39)

The first film shot of Wood Painting - a man looking up at the gloomy sky with the sun rays beaming through the clouds, the silhouette of a bird of prey and a clear message following the second shot of the film: Dies irae, dies illa! - cannot be realised on radio. While Bergman's film The Seventh Seal (1957) immediately opens the issue of the empty sky and questioning about the existence and shapes of God, the radio version of the same story named Wood Painting begins to unfold more unhurriedly. When Bergman first wrote his story Wood Painting in 1954, he had already finished a number of film, radio and theatre productions. Aged 28, Bergman entered the world of radio directing in 1946 with his adaptation and direction of Requiem by Björn-Erik Höijer. This was also the beginning of his most feverish working period. He directed two to three films a year, produced as many as eight theatre or radio plays, wrote numerous scripts and filled notebooks. In February 1951, he produced Anouilh's Medea for the radio which had been staged at Stockholm Lorens Marmstedt's Intima Teatern two months earlier. Even though he was not happy with the staging, it did not discourage him from further radio work. In the same year, the Sverige Radio broadcast his radio debut City (Staden) directed by Olof Molander. In 1952, Bergman directed as many as five radio plays. During this period, he concentrated namely on adapting the plays by his fated author August Strindberg.

We mention Wood Painting (Trämålning) in the context of Bergman's extensive radio work because it occupies a privileged position among the plays - this also applies in the 
Czech context. The morality was inspired by a medieval wood painting in a small village church depicting the 'death dance'. The story of Antonius Block, a fatigued knight returning from a crusade, and his Sancho Panza-type servant Jöns takes place during the plague. In the diseased country full of dying people, the knight and his servant meet the Witch, the Blacksmith and his riotous Wife, the Actor, the Young Girl Maria, all of them sentenced to death and accepting it in different ways. Their micro-stories culminate in the encounter with Death. He leads all of them away with the exception of nursing Maria in a picturesque procession evoking the medieval and Baroque paintings of the 'dance of death', a procession of characters marching behind Death with a scythe.

The intimate story was staged at least four times in Sweden during Bergman's life: as a radio play - adaptation of the original story Death and Knight (Riddaren och döden, 1954); as a theatre play at Malmö Stadsteater (1957); as a film The Seventh Seal (1957); and later still as a television film (1963).

The radio and theatre plays accentuated namely the existential situation of people in a country affected by the plague. The film version, however, brought another image into the minds of most viewers: Knight and Death stooping over the chessboard prolonging the lives of a growing procession of characters with every move of the pieces. In the film, Death is the permanent companion of the modest community, it watches the newcomers and tests the Knight's patience. He failed in the crusade and forbade himself the love of a woman, and now seeks the meaning of life beseechingly, pleads with the empty sky and moves the pieces on the chessboard in order to win more time. Street makes an interesting observation in this respect, referring to some desecration of the Death character in the film adaptation of the story. In Street's view, the character with white paint on their face wearing a loose black robe is: 'far less effective than it had been in the sound version of the piece, arguably only reaching a comparable point of drama in one of the closing scenes, where the character enters the room, his presence reflected in the facial expressions of those he has come to claim; visual equivalent of silence' (STREET 2014: 43-44). In the radio version, Death appears at the very end of the play, he does not speak at all, his presence is evoked by a stylized sound of the scythe. Individual characters introduce themselves to him and he, with a single line, invites them on a journey.

Wood Painting was the first Bergman's title that was broadcast on Czechoslovak Radio in 1966. The loosening political situation at the time heralded a boom in original radio production and Czech radio plays were quickly making their way to European festivals. At the same time, radio creative producers looked for possibilities to adapt modern drama by Samuel Beckett, Friedrich Dürrenmatt or Franz Kafka for radio. This is where Bergman's Wood Painting came into the picture. The director was Josef Henke who was refining his directing style at the time. It is symptomatic that his directions from the 1960s draw from themes similar to Bergman's. In the 1960s, Henke produced the dark story of the Pied Piper, a Faustian legend in a version by popular puppeteers, Kafka's The Metamorphosis as well as Beckett's Krapp's Last Tape. The roles in Bergman's Wood Painting were assigned to prominent actors of the period but we 
know little about the performance itself. Henke was among the hundreds of radio staff who were affected by the so-called normalisation in the 1970s. Since he refused to accept the Czechoslovak occupation by the Soviet army in 1968 as a 'friendly aid', he was fired from the Czechoslovak radio and a majority of his work was erased from the radio archives. Even though old programmes are sometimes retrieved from amateur recordings, Henke's dramatization of Wood Painting has not been discovered so far. However, many other Henke's plays have been preserved and this makes us believe that the reasons for destroying the analogue tape with the play were, apart from the name of the inconvenient author, the strong sound images of the play itself. One of them is the scene where Knight Block meets his wife but after years of wondering and wars he does not recognise her. What could the radio censors have thought of this dialogue during the period of normalisation in Czechoslovakia? Karin describes the situation in the country devastated by the plague and Block is unable to identify himself with his homeland.

Karin: I am Karin, the wife of Knight Antonius Block. Fleeing the plague I had to leave the house. I was one of the last to leave.

Block: And what are you doing here?

Karin: Can't you see the distant fires and can't you hear the music? They are the guards, neighbours of the country. They erected a high rampart on the border running along the whole country, from sea to sea. Everywhere behind the rampart there are foreign soldiers; no one can flee our infested land. We can all but wait.

Block: What shall we wait for?

Karin: Nothing. The plague. ${ }^{2}$

We know with certainty that the recording was erased in 1980. There was a clear connotation with a country the western border of which was surrounded with a high barbed-wired fence and where a foreign army had been settled for over a decade. This was surely the reason why Bergman was not acceptable as an author on Czech radio for many years and even as a film director he was known only to film club members.

The radio remake of Henke's destroyed recording from the 1960s was directed by Vlado Rusko in 2005. Of all Czech radio productions, it is Wood Painting that is by far the most imaginative. The plastic sound composition creates an auditory continuum of a medieval plague-ridden country. The figures from the altar piece painting become alive. The narrator and, at the same time, observer and glossator (Luděk Munzar) plays a key role. Another bonding element is the ambient music by Petr Mandel.

The director predetermined the character of his adaptation by the selection of actors. They do not psychologise their characters, they rather intentionally create the archetypes of the spiritually ascetic knight, the talkative squire, the innocent young girl, and the flippant actor. As part of the acting interpretation, Vlado Rusko uses the deep

2 Quoted from the radio play. BERGMAN, Ingmar. Wood Painting. [Radio play]. Adapted by Bohumil Sobotka. Directed by Vlado Rusko. Český rozhlas, premiere 14. 3. 2006. 
tone colours of the protagonists' voices, which in some cases were chosen against the type: let us mention the squire Jöns by Jiří Lábus. His usually sharply modulated acting in response to Rusek's direction creates an urgency with which he creates an emotion of nervous tension. Among the female protagonists, Barbora Hrzánová as Witch Tyan is of some interest. Her cold-blooded description of imprisonment and torture resembles a religious exaltation. Hrzánová's monologues (like Lábus's) add some mysterious expression to the genre of medieval legend. Luděk Munzar as Narrator makes a full use of his melodious voice and in a matter-of-fact manner, with some inevitable fatality, speaks his lines to connect the fates of the characters.

The radio narration is based on merging the Narrator's part and acting characters into a complex music-sound composition. As a replacement of Henke's destroyed recording from the 1960s, we have a Czech radio play of probably the best known Bergman's play Wood Painting.

\section{Solo for One to Three Voices}

While Bergman as a radio playwright was broadcast only once on Czech radio in the 1960s, European radios performed his plays and texts much earlier. In the 1960s, Bergman's plays had already been performed all over Europe. In 1966, the radio adaptation of Bergman's film script Wild Strawberries was produced in West Germany (directed by Rudolf Noelte) and in Hungary, director György Lengyel recorded a new version of Staden (A város, 1971). ${ }^{3}$ Bergman himself made radio recordings regularly until 1961. ${ }^{4}$ After a very long intermission he got back to radio in 1984. The impulse was A Hearsay (1984), a play by his life-long friend Erland Josephson. Josephson had been an actor in many of Bergman's films and was the director of the Stockholm Royal Dramatic Theatre. The last time Bergman directed for radio was Strindberg's The Pelican/ Island of the Dead (2003). Even though Bergman did not direct large theatre performances in his old age, at the age of 83 he directed Ibsen's John Gabriel Borkman for radio $(2001) .^{5}$

In the Czech Republic, ten original Bergman plays have been recorded and they will be further discussed in some detail. Following is a chronological list of Czech radio performances of Bergman's works. It indicates that Czech radio became greatly interested in his plays in the $1990 \mathrm{~s}$.

1966: Malba na dřevě, dir. Josef Henke. The first Czech radio production of Wood Painting

3 Information on international productions is available, for example, at http://nostalghia.cz/pages/andele/ bergman/filmy.php.

4 The complete summary of Bergman's radio plays and directions is available at https://sv.wikipedia.org/ wiki/Lista_\%C3\%B6ver_Ingmar_Bergmans_radioteater.

5 A more detailed summary of Bergman's directions on the radio and brief annotations to plays are available at http://www.ingmarbergman.se/en/productions/theater/radio. 
1990: Laterna magica, dir. Alena Adamcová. A reading of Bergman's autobiography

1991: Záležitost duše, dir. Josef Melč. The monodrama A Matter of the Soul

1993: Dobrá viole, dir. Hana Kofránková. A twelve-part reading of the memoir book The Best Intentions

1996: Po zkoušce, dir. Jan Kačer. An adaptation of a television production After the Rehearsal

1997: Scény z manželského života, dir. Zdeněk Štěrba. Six dramatic dialogues from Scenes from a Marriage

2005: Malba na dřevě, dir. Vlado Rusko. The second production of Wood Painting

2006: Sarabanda, dir. Miroslav Buriánek. A four-part dramatic reading of Bergman's final script

2012: Nevěra, dir. Hana Kofránková. An auditory adaptation of the film script Faithless

2018: Sarabanda, dir. Štěpán Pácl. A new production of on the occasion of Bergman's $100^{\text {th }}$ birthday.

It is clear that Czech radio dramaturgy chose Bergman as an author in a rather random way. Apart from Hana Kofránková, no director chose to direct a work of Bergman's more than once. In some cases, however, the authors did have a deeper relationship with Bergman. Actor Jan Kačer studied the role of director Vogler in 1998 on the chamber stage of the National Theatre Prague in Kolowrat, having previously directed After the Rehearsal (1996) for radio. As for Miroslav Buriánek, he was as enchanted with Bergman's film language as he was with that of other film directors (Eisenstein, Tarkovsky, Allen). Buriánek was also the one most inspired by the film medium and his Saraband was directed strictly as individual 'scenes' while preserving Bergman's notes to the work's visual aspect.

Let us look at the radio productions for one to three voices for examples of Bergman's script-writing conciseness which does not stand in the way of a large dramatic arch while offering remarkable acting opportunities.

The director Alena Adamcová produced Bergman's memoir Laterna magica as a seven-piece reading in 1990. The director's memories were interpreted by Rudolf Pellar, an outstanding Czech poet, reciter and radio actor. Pellar achieved a suggestiveness of expression by minute work with breathing and silence. Similarly, the poet Seán Street believes that silence before words, the 'opening silence', is not 'dead air' but, on the contrary, it is 'the moment of infinitive possibility' (STREET 2014: 38). Even though Bergman seemingly followed the typical scheme of the memoir genre (from childhood memories to professional growth and final stocktaking), in many respects Laterna magica goes beyond a standard biography. Bergman openly admits the Nazi fanaticism which he was unable to resist during his studies in Germany in the 1930s. The subsequent re-examination and apprehension when the horrors of war came to light stigmatised him for the rest of his life. With the same openness Bergman speaks about his childhood, the centre of gravity of many later themes. He confesses his fascination with Andrei Tarkovsky's films and 
his relationship with the theatre and film art giants like Laurence Olivier, Charlie Chaplin or Greta Garbo.

The intimacy is evoked by the confessional atmosphere which Bergman used in some of his film scripts. Rudolf Pellar, as Bergman's voice, carefully captures the inner tension as well as the nostalgic tone that the director gave to his memoirs. The prudently suggested sentiment and human and professional retrospect in Pellar's interpretation resemble the concrete fictional characters in Bergman's later texts: from the point of view of a professional confession it was director Vogler from After the Rehearsal; from the point of view of the life retrospect it was the ageing Johan from Saraband. A typical motive is Bergman's incessant tormenting tendency to self-doubt, verification of his own value and uncertainty about the correctness of various decisions. They concerned both professional and, more often and the more painfully, personal attitude towards women, children, and parents. The high expectations of himself and people around him naturally stem from doubt. Laterna magica signalled the demand for Bergman's texts after 1990. It is interesting that radio authors reached namely for Bergman's later texts (with the exception of Wood Painting). In them, the author exploited their own life and script-writing experience. They are suitable for the radio because they make use of the intimate setting and such type of dramatic conflict to which the auditory medium offers new perspectives of meaning and artistic interpretation.

In 1991, Josef Melč directed Bergman's monodrama A Matter of the Soul with Iva Janžurová in the title role of Victoria. A year earlier, Bergman had been awarded the prestigious Prix Italia for his own direction of the play with Jane Friedmann in the lead role. The play itself was written in 1972 and therefore we must place Victoria, a lonely middle-aged woman, somewhere between the heroine in the film The Touch (1971) and the three sisters in the film Cries and Whispers (1973).

Director Josef Melč approached Bergman's monodrama at a mature age as a director who became famous for his multi-year project of radio readings, We Read the Bible (Čteme Bibli 1996-2002) or adaptations of F. M. Dostoyevsky's masterpieces. Among the Czech directors, it was Melč who put absolute trust in the dimension of silence and often used it in his sound realisations. For example, in the two-hour adaptation of Dostoyevsky's Idiot (1982), he managed to create such absolute concentration on the acting that he did not need any music between the scenes. For him, silence is a fully-fledged sound expression with which he stimulates the listener's imagination and visual aspect of the auditory piece, as expressed by Donald McWhinnie: 'During silence, things happen invisibly, in the minds of the players and in our imagination' (MCWHINNIE 1959: 88). In realising Bergman's monodrama, the director Josef Melč gave Iva Janžurová lots of space for displaying many facets of her talent. Iva Janžurová, namely at the beginning of her career, won great renown as a comedienne. In Melč's making of A Matter of Soul the fifty-year old actress shows an ability of an intense auditory introspection thanks to which she is able to disclose the mental state of a psychiatric patient. The expressive facet that Janžurová shows in the role of Victoria is a feature typical in Bergman's characters. Janžurová works with many sharp contrasts in intonation, an ability that helped her to success in comedy. However, in this play she cumulates them in a passionate 
expressive stylisation; she often changes the expressive value, while modulating her voice into many tones with great confidence. Janžurová presents the sometimes exaltedly rapid cadence of speech with confidence. Her Victoria confirms the thesis that 'speech is the expression of inner life' (BROOK 1973: 1). With this absent-minded overexposed utterance, she brings to life an image of an unstable woman for whom the reality merges with fiction and memories.

Jesse Kalin formulates one of the principal thesis of his approach to Bergman's work in an idea about the importance of places where individual stories are situated: 'From his first pictures on, the character of the places in which his subjects and their stories are set is always significant and conveys in its physical features a representation of important elements of their spiritual struggles' (KALIN 2003: 2). This is fully true in the context of the Czech radio productions of Bergman's work. It is not a coincidence that Janžurová's Victoria holds her tormenting monologue in a psychiatric hospital where her fables merge with real memories, and her desires with irrational demands on absent persons.

Ingmar Bergman never ceased writing and in his later years even released previously unpublished scripts. Each and every year of his professional timeline includes a number of written sketches, theatre and radio plays or television films. ${ }^{6}$ However, the increasingly inward tone of Bergman's later themes becomes even more prominent in his radio adaptations. The radio concentrates the field of force in the emotional message and the existential spiritual foundations in words, in the non-verbal hint or pause that often tell more than an explicitly displayed image. Jesse Kalin sums up Bergman's late work through the optics of the film Fanny and Alexander, but his words can be applied to the late radio works as well:

Life is seen as not even anticlimactic but from a point of ultimate detachment and disinterested observation (like that of a visiting anthropologist). The rage and anger of the 1970s is gone, as is its despair and yearning for answers. Both questions and complaints have been superseded by a simple knowledge: This is what life is, what it will be for others, what it has been for us, and there is nothing more to say. At the end, we are left alone on the stage and the lights go out. (KALIN 2003: 186)

The radio play After the Rehearsal has exactly these features, being an auditory version of the television film from 1984 where Bergman's favourite actor Erland Josephson made a star appearance. The closed-in drama taking place on a theatre stage following a rehearsal of Strindberg's A Dream Play carries in it the essence of Bergman's views on the stage art, actors and theatre life in general. In the monologues of the ageing director, there is always the omnipresent and almost obsessively re-opened topic of the painful relationship between a man and a woman, their love, betrayal, infidelity and mutual inspiration. The Czech radio production of the play was directed by Jan Kačer.

6 The timeline of film, television, radio and theatre including texts, diary entries, scripts, stories and other documents are available at http://www.ingmarbergman.se/en/universe. 
Kačer's concise direction took advantage of Bergman's analytical precision with which the inner dynamics of the dialogue and the relationship conflicts between the director Vogler (Lubor Tokoš), actress Anna Egerman (Barbora Kodetová) and her mother Rakel (Nina Divíšková) resound. The minimalist direction which works only with the dialogues and suggested piano music, enabled the dense content of the text to stand out, namely the contrast between the old world (Vogler) and the youth (Anna). In the role of Vogler, Lubor Tokoš created one of his greatest radio pieces. Vogler is presented as a demanding artist fully dedicated to his craft, theatre mission and art.

Vogler represents Bergman's idea of the theatre world at many levels: the level of artistic obsession, loyalty to the theatre, despotic attitude to actors as well as the permanent need to define himself in his work and never stop looking for the sources of artistic activity. He finds inspiration in his own childhood, family, lives of beloved women, and colleagues, but mostly in his own self. Bergman's alter ego mercilessly searches through every fold of his life motivations, convicting himself of many failures without sentiment. The permanent doubts alternate with heartfelt confessions to the theatre art which Kačer accentuates with the piano melody. Tokoš's typical voice colour strips the basic values of the artist's life, for example his relationship with the playwright August Strindberg, whose theatre plays had a forming influence on Bergman and he produced many of them on radio and in theatre. ${ }^{7}$ At the time of recording After the Rehearsal Tokoš was seventy-three, he was a mature actor and an experienced radio interpreter, his voice colour suited the intention to create a moralistic and retrospective direction. In the television film After the Rehearsal, the viewer mainly perceives the physical emotional tension building up among the characters on the confined stage. The radio version emphasises the density of lines and strong messages that Tokoš plants in every sentence. In order to create the image of the old director, the actor works actively with his breath, using it to show tension and emotional shiver. He does not hesitate to show the passion which is still in Vogler at his old age. Like Bergman, Tokošs Vogler is a highly sensitive artist who achieves truthfulness through self-exposition. After the Rehearsal works with the topic of manipulation, which the director intentionally uses to achieve the actors' best performance. He repeatedly speaks about: his fascination with acting, the actors, their mission and difficult lot. He states: 'A real actor will always get to them (the audience). He will reach the goal regardless of the role, other players, director, stage design. He touches, haunts, lives. ${ }^{8}$ Vogler hardly makes a distinction between stylisation and real life, he strives for an absolute authenticity freed from all bad habits that actors tend to acquire. He wants to stage Strindberg's A Dream Play exactly as it was written, not a single word more or less. Through Vogler's mouth, Bergman protests against the violation of authors such as Strindberg or Ibsen. In his view, the

7 The choice of Strindberg's play as the fabrication framework for the script of After the Rehearsal was naturally not coincidental. Bergman felt to be connected with Strindberg much more intensely than as a mere director staging a Strindberg's piece: 'I tried to write like him, dialogues, scenes, everything. I felt his vitality, his anger inside me' (TORNQUIST - STEENE 2007: 11).

8 Quoted from the radio play. BERGMAN, Ingmar. After the Rehearsal (Po zkoušce). [Radio play] directed by Jan Kačer. Český rozhlas, 1996. 
pieces do not need any updates if they are able to address the audience.

In places where there are two or three actors in the play, there is plenty of room left for the unfinished sentences, as is usual in conversation; the moments of silence in which ideas are born for Vogler's further monologue; the moments of silence in which Anna Egermann finds an opportunity for empathising with the ageing director; the moments of silence in which the dispassionate Victoria looks in the mirror first thing in the morning and that look stops the flow of her speech for a moment. Street calls these situations the 'golden moments' describing them as the 'moments of audio stillness, where the audience and the maker come closest, touch, and sometimes imaginatively dance' (STREET 2014: 46). If Bergman's intimate plays evoke the imaginary feeling of peace, his later pieces bring a much more oppressive realisation and merciless squaring of accounts with life.

\section{The Dark Tones of Saraband}

It was not a coincidence that we opened this paper by quoting the script to Bergman's Wild Strawberries. The motive of a man looking back at his entire life and fearing the approaching death typically winds through all Bergman's radio productions. The radio as a medium seduces authors to use this meditative and contemplating setting. Bergman's stories of a man who carries the meaning of life in himself and yet stubbornly looks outside for answers to his questions, are perfectly suited for the radio. People forget that they will find the straightest answers inside themselves. Or they are unable to listen to themselves, find answers in their own inner silence and trust them. Often it requires a tragedy or its touch for people to wake up and mobilise their life strength and pronounce the inner truths that have been denied for years. These are the situations of Bergman's heroes in larger radio opuses about which we discuss in the final part of the paper. Similarly, to Isak Borg, they set out on a journey to find out what is still authentic in their lives and what has become a comfortable lie.

The autobiographic point of departure gave Bergman the truthfulness of utterance as well as enough room for creative fabrication. The radio drama Faithless (2012) creates a faithful image of an author who is working on finishing his new play in the isolation of his house on an island and lets an actress meant for the lead role read the play. Bergman openly re-creates his own love affairs and even keeps his own name as the writer. ${ }^{9}$ He does not spare any of the three central characters. The tragic consequences of infidelity are amplified by the character of daughter Isabelle, the child, victim of the love triangle. However, this time the intense burden of guilt is left by Bergman the author and Bergman the character on the woman, actress Marianne.

Director Hana Kofránková cast Dana Černá as Marianne, Ivan Trojan as David, Lukáš Hlavica as Markus and Jiří Ornest as Bergman. Namely Černá and Trojan in often

9 In the film Faithless Bergman was impersonated by Erland Josephson. The film according to Bergmans's script was made by Liv Ullmann in 2000. 
very expressive situations grasped the typical bergmanian outlines of their characters: the fragility and intensity of enjoyment which the actors cumulate in various voice modulations. Trojan's David becomes monstrously pathological in the scenes where he tortures Marianne. The actor uses David's emotional outbursts to plastically depict David's instinctive desire for revenge and humiliation of the ex-lover. Trojan's use of voice suits Bergman's emphasis on the momentary loss of self-control; this frequent weakness of Bergman's male characters is especially prominent in the moment when David rapes Marianne.

The highly sophisticated structure of Faithless deserves a more detailed discussion, namely for its elaborate dynamics of movement between the framing situation and the story. The story is mostly linear and narrated by Marianne who tells of her infidelity. Her memories are presented in a retrospective way where she typically leaves out the most interesting moments when the lovers become intimate but does not hesitate to remember various details, seemingly unimportant images that she recalled some time later. The chain of events becomes loose at the and, as Marianne announces, the fates of individual characters become increasingly complicated and bound for disaster. In several scenes following in quick order we learn about the future fate of daughter Isabelle who was unable to recover from the parents' breakup for ten years. Other key moments in Marianne's life are suggested, including the necessity to cope with the exhusband's suicide and remorse. Marianne states very laconically how she broke up with her lover and how she ended an affair which had ruined her life, taken her daughter and husband. But this is at the very end of the play and the actress steps out of the role and reflects on the character of Marianne. Without knowing the end of the story, she almost does not empathise with the character. The distancing alienation of an actor is not a usual radio drama or staging practice, and this is why in Bergman's play it is so interesting.

An authentic image of the breaking up of previously heartfelt love relations is undoubtedly rooted in Bergman's own experience. In hints, he plants his own alter ego in several characters at the same time (Bergman, director David, conductor Markus). Enchantment and disenchantment oscillate in close contact and all that is left is the deterrent squaring of accounts with the guilty parties. However, who is guilty and who is the victim in Faithless? Bergman gradually argues in favour of all vertices of the triangle, does not side with anybody; the resignation and humbleness of the guilty ones leads to a greater and greater contradictoriness.

The chronology of Bergman's work closes with Saraband, a script which Bergman presented as a television film in 2003. It was produced for Czech radio by director Miroslav Buriánek as a four-part dramatic reading.

A strong story of a relationship between parents and children has the theme of a lifelong traumatising absence of love, deep grievance, misunderstanding, and the inability to empathise. To a great extent, Bergman draws from his own experience as a son of an evangelic pastor. Bergman had already come 'to terms' with the father in his 1950s films, mostly in Wild Strawberries. At the same time, Bergman finds inspiration in his own fatherhood. He was the father of nine children. The confession of problematic re- 
lationships in the family in the form of a dialogue strips, sometimes almost aggressively, the painful spots of the hierarchy of family and partner relations. This thoroughly modern text in which Bergman acknowledges the Ibsenian poetics, bears witness to the short time which the unusual quadrangle of ageing Johan, his ex-wife Marianne, the son from Johan's second marriage Henrik, and his daughter, Johan's grand-daughter Karin. The fragile equilibrium of relations is paradoxically maintained by Anna, Henrik's wife who had died two years earlier and who they had all loved in their own ways. The awareness of mortality and the looking for the imprint of eternity are the topics of many Bergman's texts but in this last one Bergman does not succumb to sentimentality. In Saraband, he intensifies the effect of roughly portraying the four characters among other things by the fact that they were modelled on characters from Bergman's previous pieces. The earlier fatal problems of infidelity, financial bankruptcies or son's hatred to the father appear to be of marginal importance now, face to face with the imminent death. Each of the characters has to find a priority in a crucial moment of their lives, detach themselves from the petty grudges and preserve their authentic being even if it is at the cost of parting with the family and people close to them.

The four-part dramatized reading offered exceptional parts to excellent actors, namely Otakar Brousek and Růžena Merunková as Johan and Marianne. Director Miroslav Buriánek skilfully maintained the pace of the unhurried but inexorably culminating conflict all the way to the final escalation where both the characters and the audience experience some sort of a catharsis. In Saraband, Bergman opens up the most intimate zones of his own life while appealing to the general human values. And similarly to After the Rehearsal, he pays tribute to art, this time to the music with an emphasis on his beloved J. S. Bach. Once again, he conjures the image of an abandoned village church with the painted scenes and with quiet music, offering space for contemplation. The quiet scene where Marianne and Henrik meet precedes a dramatic night scene where Johan, thoroughly paralysed by his fear of death, comes to Marianne. He cannot speak about his fear, he can hardly manage to define and describe it. He remains silent and longs for the physical closeness of another person. 'Since modern man fears death as none before him, he avoids silence to nourish his fantasy of perpetual life' R. Murray Schafer observes. 'In Western society, silence is a negative, a vacuum. Silence for Western Man equals communication hang-up. If one has nothing to say, the other one will speak. Hence of garrulity of modern life which is extended by all kinds of sonic jabberware' (SCHAFER 1994: 25). The radio direction is very unemotional in sketching the strongly visual image of a naked old man who lies down with the only close being in the house and tries to chase away his fear using the impersonal voice of the narrator. He also continually assures the audience that all that they are listening to is a mere script from another audio-visual medium. He attends to the character of the scene in a similar way, describing the non-verbal reactions of characters and their acts; sometimes one hears a mention of the emotional state of the characters. The sound of an old projector leaves no doubt that one is watching film scenes. The public pronunciation of painful traumas purges the characters in the story but also the author who in this way concludes his artistic and philosophical legacy. 
The theatre director Štěpán Pácl staged Saraband for Czech radio again in July 2018. In his direction he followed a different method than Buriánek. A shorter footage of the play makes it possible to put more emphasis on specific aspects of the story and to describe the characters. While Buriánek cumulated most of the tension in the acting, Pácl works more with the sound design. The sound composition accentuates the nervous states of the characters while their complicated relationships are captured in acting as well as in sound. The sound implies the inner rage that is symptomatic of Bergman's characters not only in this late work. The usual centre of gravity in Bergman's radio dramas is in the acting expression and silence but in this direction Pácl composes the conflicts among characters and the 'emotional quality of dialogues' (VENCLOVÁ 2018) by the sound element. In comparison with Buriánek's reading, Pácl's staging leaves a rather hasty impression and the psychology of characters is not as profound as in Buriánek's directing. On the other hand, it offers a more multifaceted sound expression following the intentions of modern auditory directing.

\section{Conclusion}

We looked at Bergman's radio work placing an emphasis on plays broadcast in the Czech Republic. While Bergman (director) and Bergman (author) worked on Swedish radio from 1946 to 2003, the Czech versions of his plays and other texts began to emerge in the 1960s and then again in the 1990s. Thus, the Czech authors logically reached for Bergman's later works, those that we described as stock-taking, concluding the work. Many authors were prone to more optimistic stylisation or simpler and more accessible genre forms, creating the feeling that the 'world is good' toward the end of their careers. Bergman concludes his work with socially grave and not exactly encouraging pieces. This also applies to the Czech radio productions of Bergman's work. While After the Rehearsal at least suggests some hope and the permanent positive creative desire of director Vogler, neither Saraband nor Faithless offer any such optimistic outlook. The inner tragedy of the characters illustrates the increasingly alienated world where there is no room left for understanding. On the contrary, the fatality of some moments in people's lives is emphasised. In Bergman's principal works from the 1950s and 1960s, the life anxiety was a companion in fabricated stories and visual experiments. In the texts from the mature period, the same anxiety is the basic motivation of the characters' contemplation of the sense of existence and possibilities of satisfaction in life.

As regards the sound expression, in the Czech radio adaptations of Bergman's texts there is neither a clear and homogenous dramaturgic concept nor a uniform style of staging. Individual productions vary in genre as well as in the persons of directors who have their own specific creative methods. An identifiable feature of the Czech Bergman recordings is the shift towards expressive acting which is predetermined by the way the characters were written by Bergman, their profound psychology, complicated relationship motivations and personalities. As regards the directing, we find 
an accentuated element of silence which in the world of Bergman is associated with anxiety and often an implied spiritual overlap. However, in the sound composition the silence does not only acquire a meaning, it also bears an aesthetic function. It contains its own dramatic value while slowing down the tempo of the play. Silent horror accompanies the character of Death in the early radio play Wood Painting, silence accompanied by breathing emphasises the professional confession of director Vogler in After the Rehearsal. In the monodrama A matter of the Soul, silence is a fully-fledged narrative means along with music and sound - the only female voice needs silence as a tool to create space, to change emotions and to let an idea die away. The silence of Bergman's late plays (Faithless, Saraband) corresponds with Seán Street's description of such moments of radio perception when 'maker and listener come closest in their imaginative partnership.' In such instances Street understands silence as 'a moment of terror, the possibility of its existence being broken by some unseen, threatening presence or act' (STREET 2014: 39).

This shift towards pessimism may be associated with Bergman's permanent accentuation of the duality of ways of which Jesse Kalin speaks - does life offer any sense and mercy or not? (KALIN 2003: 18). Like Kalin, who states the similarity of topics in Bergman's film production, we find some topics in Bergman's radio productions with which the author was coping in one way or another throughout his life. The stripping of emotions, moods, changes in relationships, fragility and vulnerability of human soul, all this became the omnipresent horizon of artistic imagination for Bergman. In his films, it was realised by the innovative work with the light tones, original camera work or acting creations by the dedicated actors Liv Ullmann, Bibi Andersson, Erland Josephson or Max von Sydov. On the radio, this is substituted by an emotional expression of acting interpretations and sound minimalism that lets the text stand out. 'Listening has always been /.../ a solitary thing; we all hear our own programme, just as we all read our own poem.' Seán Street offers as a possibility to listen to the radio and find a way to Bergman's way of thinking which, through the radio, is reflected in our own fates and the repeatedly posed existential questions (STREET 2014: 123).

\section{Bibliography}

BERGMAN, Ingmar. 1960. Four Screenplays of Ingmar Bergman. New York: Simon and Schuster, 1960.

BLÁHA, Ivo. 2004. Zvuková dramaturgie audiovizuálního díla. Praha: Akademie múzických umění, 2004.

BROOK, Peter. 1973. Foreword by Peter Brook. In Cicely Berry. Voice and the Actor. New York: Wiley Publishing, 1973.

CROOK, Tim. 1999. The Radio Drama. London: Routledge, 1999.

HAND, Richard J. and Mary TRAYNOR. 2011. The Radio Drama Handbook. Audio Drama in Practice and Context. Londýn: Bloomsbury, 2011. 
KALIN, Jesse. 2003. The Films of Ingmar Bergman. Cambridge University Press, 2003.

McWHINNIE, Donald. 1959. The Art of Radio. Londýn: Faber \& Faber, 1959.

SCHAFER, R. Murray. 1994. The Soundscape. Our Sonic Environment and the Tuning of the World. Vermont: Destiny, 1994.

SHINGLER, Martin and Cindy WIERINGA. 1998. On Air. Methods and Meanings of Radio. London: Bloomsbury, 1998.

STREET, Seán. 2014. The Poetry of Radio. The Colour of Sound. London and New York: Routledge, 2014.

TORNQUIST, Egil and Birgitta STEENE. 2007. Strindberg on Drama and Theatre. Amsterdam: University Press, 2007.

VENCLOVÁ, Renata. 2018. Ingmar Bergman: Sarabanda. Czech Radio (14. 7. 2018). Available online at https://vltava.rozhlas.cz/ingmar-bergman-sarabanda-7565948.

\section{doc. Mgr. Andrea Hanáčková, Ph.D., Mgr. Tomáš Bojda}

Department of Theatre and Film Studies

Palacký University Olomouc, Czech Republic

andrea.hanackova@upol.cz, tomas.bojda01@upol.cz

Andrea Hanáčková teaches the theory and practice of radio production in connection with interdisciplinary links between radio, theatre and film. She mainly focuses on issues of radio genres and formats, radio documentary and feature with an emphasis on the role of the author and his/her performance, audionaratology and structuralist approach to the auditive programme.

Tomáš Bojda focuses on the radio acting theory as a Ph.D. student. He is currently writing a thesis in which he sums up his research on the creative collaboration between the actor and the radio director. 